ライカイ・ジョンボル・ティボル（著）

\section{変容する親密圈／公共圈 9}

競合する家族モデル論
2014 年, 京都大学学術出版会,

ISBN 978-4-87698-393-3, 定価（3,800 円十税）

\title{
渡辺秀 樹
}

本書は, 家族研究のパラダイムとパラダイム転 換の国際比較研究である. 比較の沮上に載るのは 家族社会学のテキスト（教科書）であり, 刊行時 期の異なるテキストを各国 2 冊取り上げ，両者の 内容を分析し，その間の変化を著者の枠組により 整理し議論するというものである，比較対象とす る社会は，ハンガリー・中国・台湾・日本の 4 カ 国である、東ヨーロッパと東アジアの社会が対象 ということになる.

本書の目的は,「具体的には, 家族社会学テキ ストの比較研究を通じて，そこに表象されるさま ざまな家族概念，イデオロギー，モデルのありよ うを分析の対象とする。そうしたうえで，『(近 代）社会の単位は（近代）家族である』という従 来のパラダイムから『個人に焦点をあてる』いわ ゆるポスト近代的パラダイムへの転換が起こる様 子について検討すること」（はじめに）とされる.

各国で先行する 1 冊目のテキストは 1980～90 年前後の刊行であり, そして 2 冊目のテキストは 21 世紀初頭に出版されたものである. ハンガ リーの場合, 2 冊の刊行の間に 1989〜91 年の〈べ ルリンの壁崩壊〉からソ連・東欧の政治体制の変 化に至る激動期を挟む. 政治的次元と同様, 家族 社会学というひとつの学問領域においてもパラダ イム転換を予期するに相応しい時期である，東ア ジアの国々も, 〈社会主義市場経済〉, 〈経済的奇 跡; economic miracle〉, 〈近代の問い直し〉といっ た激変期と並行している。「家族構造の変動が西 欧北米に比べはるかに複雑な様相を呈する非西欧 文化圈に焦点をあて」（はじめに）ている。

各国 2 冊のテキストを選ぶ方法は, 現地調査を 踏まえている. 著者の現在の在住地である日本以 わたなべ ひでき: 帝京大学
外の国（ハンガリー, 台湾, 中国）については, その国を訪ね複数の家族研究者にインタビューを し，家族関連の文献・資料を収集するという作業 をしている。そして，各国の家族社会学の学史的 検討を加えたうえで，家族関連のテキストのリス 卜を作成してそこから分析対象の 2 冊を選ぶ.こ の作業は著者の多言語を駆使する能力を前提とす る（著者は韓国を対象にできなかったのは言語能 力の限界によると述べる．本書はネイティヴ・ チェックを経た日本語で書かれた研究書である). 分析軸の源泉あるいは土台となる西欧北米の家族 社会学に対する堅実な学識と対象とする各国の家 族社会学の動向の広範な理解を前提としている. 東ヨーロッパと東アジア諸国を対象とする研究で あれば，前者にはハンガリーだけでなく，もう 1 カ国加えるのが適切ではないかという感想もあり うるが, 著者自身による現地調査と対象国の言葉 で書かれた文献の読解に基づく研究の意義を多と すべきであろう．現代の家族社会学の主要課題の ひとつである国際化に呼応する果敢な実践である.

構成（目次）は，以下のとおり.

第 1 章 家族の比較研究に潜在する可能性をめ ぐって.

第 2 章 本書における概念の定義と分析枠組み.

第 3 章 社会主義期からポスト社会主義期へ転換 するハンガリー。

第 4 章 閉鎖的社会から開放的社会へ歩みつつあ る中国.

第 5 章 伝統文化とアメリカ文化との葛藤に陥つ た台湾.

第 6 章 脱亜から入亜へ転換する日本.

第 7 章 家族社会学の多様性.

第 8 章「競合する家族モデル」論の構築. 
(付録として, 取り上げた各国 2 冊, 総計 8 冊 のテキストの内容要約を掲載している.)

第 1 章では, 分析の準備として, 〈パラダイム 転換〉に強く関わるイデオロギーとしてのナショ ナル・アイデンティティや本書におけるくパラダ イム転換〉の主軸となる「個人化（ある固定的な 家族規範から解放されつつある一方で, 個人のラ イフスタイル選択に関する自由が増大する過程を 意味している;「はじめに」)」に関わるミクロな 人間関係の実態を概観する。そして，本書で用い る〈パラダイム〉および〈パラダイム転換〉の定 義の特徵をイデオロギー性に求め, それに基づい て分析対象となる非西欧文化圈の家族社会学につ いて論じ, 〈四大概念的資源〉として, 〈プレ近 代・資本主義近代・社会主義近代・ポス卜近代〉 という概念を導出する.

第 2 章では，「イデオロギー的資源（ideological sources）」の意味を明確にする。これは上述の概 念的資源のイデオロギー性に注目したものであ り，１。プレ近代的（たとえば，キリスト教や儒 教思想による）家族イデオロギー，ii. 資本主義 的近代的（とりわけ米国中心 [パーソンズの］近 代家族モデル論的）家族イデオロギー, iii. 社会 主義的近代的（マルクス思想的）家族イデオロ ギー, iv. ポスト近代的（個人に焦点をあてる） イデオロギーを説明する. 続いて, 分析枠組を提 示する。すなわち，取り上げられたテキストは， i 理論的方向性（テキストがどのような文献を参 照しているか量的に把握したうえで質的な考察を 行う), ii 方法論（テキストが依拠するアプロー チの特定を行う), iii モデル分析（1)社会の最小 単位は家族か個人か. (2)多様性に関する寛容性. (3)家族関係の民主化. これら 3 点に加えて以下の 2 点によって構成される, (4)対比するイデオロ ギー資源＝テキストがどのようなイデオロギー資 源を意識しているか. (5)モデル作成の時間性 $=$ べ クトルが過去志向か／現状維持志向か／将来志向 か）という統一された枠組で分析される.

その具体的な展開が第 3 章から第 6 章である.
第 6 章の日本においては，森岡清美・望月嵩 （1983）『新しい家族社会学』と目黒依子（2007） 『家族社会学のパラダイム』が選ばれている。第 7 章は, 4 力国の分析を踏まえた知見の提示であ る. 4 カ国のテキスト分析から読み取れる物語を 整理し, 日本においてパラダイム転換が起きたこ と，それにともない「近代」という中心概念を含 め 4 力国の間で概念の不一致が見出されたことを 踏まえて「アカデミックな共通言語」(p. 217) の 構築の検討を指摘する。第 8 章では本書の議論の 総括を行う. 各国のテキスト分析から 4 つのタイ プを抽出し整理する。そして, アイデンティティ としての家族・「競合する家族モデル（=テキス トの分析により現れる言説的な家族モデル)」論 の要点/家族社会学におけるパラダイム転換と今 後の展望が述べられる。

著者の試みは, ひとつの大胆な枠組の提示とそ れによるテキスト分析に基づいてパラダイムの同 定と変化に接近して刺激に富む. 対象となった各 国（とくに日本語によって書かれたのだから日 本）の研究者には，本書を踏まえてパラダイム転 換（その生起の有無を含めて）の過程を具体的か つ詳細に検討することを刺激する。著者の的確な 内容の要約にあるように目黒依子のテキストは, 目黒の家族研究のいわば集大成とも呼べるもの で, 1970 年代初出を含む論文集成という特徴を もつものである（渡辺秀樹の書評, 2007, 図書新聞 2844 号を参照).つまり同書は, 森岡清美・望月 嵩のテキスト刊行以前に書かれている論文を 3 編, 同時代（80 年代）に交差して執筆された論 文もいくつか含まれる。なかには，森岡らとの共 同研究や編著論文もいくつもある.

このことを考えると, 著者のいうパラダイム転 換は, 日本の場合, 諸パラダイム間の相互影響や コンフリクト, ヘゲモニー争い（あるいは対抗的 相補性の模索）の錯綜的なプロセスを経ている. この錯綜的な変化をより詳細に明らかにするとい うわれわれの課題を喚起している. 